UNIVERSITY

OF DEBRECEN

FACULTY OF

HeALTH

NYÍREGYHÁZA

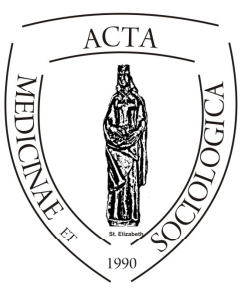

ACTA

MedSoc

VOLUME 6.

2015

\title{
A természetes szociális védőháló vizsgálata egy nyíregyházi alapítvány klienskörében
}

\author{
Virág Ádám \\ Debreceni Egyetem Egészségügyi Kar, \\ Szociális Munka és Szociális Gazdaság mesterszak
}

\begin{abstract}
Absztrakt. A vizsgálatom egy szűk társadalmi réteget céloz meg. Egy nyíregyházi alapítvány családsegítő szolgálatához forduló klienskör egyéni kapcsolati hálójának (egocentrikus network), és ebből következő makrotársadalmi integrációjának mérését végeztem félig strukturált interjúk készítésével. Azt vizsgáltam, hogy az egyén társadalmi struktúrában elfoglalt helye (életkor, lakhely, foglalkozás, jövedelmi viszonyok) hogyan alakítják kapcsolatrendszerét.

Leszögezem, hogy a munkámban megjelennek szubjektív elemek, hiszen ebben a témában hasonló jellegű felmérések nem jellemzőek a segítő szakmában. A korábbi

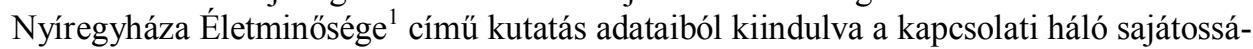

1 A Nyíregyházi Polgármesteri Hivatal Szociális Osztálya és a Debreceni Egyetem Egészségügyi Karának Társadalomtudományi Tanszéke 2008-ban indította a Háztartáspanel elnevezésű kutatássorozatot. Célja a városlakók életminőségének folyamatos figyelemmel kísérése, a változások elemzése és bemutatása. A kutatási program nemzetközi és hazai mintákon alapul, mely az ún. háztartáspanel módszertanát követi. Ennek lényege, hogy elsődlegesen a városi háztartásokról gyüjt információkat, másodsorban a háztartástagok meghatározott jellemzőiröl. Sajátossága, hogy azonos lakossági mintán, 
gait térképeztem fel. Célom volt, hogy a segítőnek olyan információkat nyújtsak, amelyekkel a klienskörük kapcsolati hálóját erősíteni tudják. A kérdések a rokoni, baráti találkozások gyakoriságára, a foglalkozásra, klub vagy szervezeti tagságra irányultak. A munkahelyen vagy annak hiányában fellépő érzéseket, a munkahelyi kapcsolatokat, a munkahelyszerzés egyéni lehetőségeit is érintettem. Az utolsó blokkban pedig a szabadidő - eltöltésre, illetve az iskolában kötött baráti kapcsolatok intenzitására fókuszáltam. Fontosnak tartottam megvizsgálni, hogy egy szociálisan hátrányos helyzetben élő ember kapcsolati hálója mennyiben tér el az átlagos nyíregyházi felnőttekétől.

Vizsgálatom eredménye: a társas támogatás alakulásának formája a hátrányos helyzetben élő emberek esetében változó képet mutat, a közeli és erős kapcsolatok (családtagok) kezdenek kifogyni az adható támogatásokból, ezáltal esetükben nem ők jelentik elsősorban a társas integráció útját.

Kulcsszavak: egyéni kapcsolati háló, integráció, rokoni kapcsolatok, baráti kapcsolatok, szolidaritás

Abstract. My study targets a narrow segment of society. With the help of semistructured interviews I surveyed the personal social networks (egocentric networks) of the clientele of a Nyíregyháza based family support foundation, and the extent of their macrosocial integration arising as a result of said networks. I analysed how social networks are shaped by social standing and position within the frame of society (i.e. age, place of residence, occupation, and income).

I must point out that my work is not without its subjective elements, as similar studies of this topic are not typical in the profession. Basing my work on the data of a previous study, titled Quality of Life in Nyíregyháza1, I aimed to map the characteristics of social networks. My goal was to provide social workers with information with which they can help their clientele in expanding their social networks. The interview questions asked about the frequency of visits to friends and family, about employment status, and about membership in clubs or other organisations. I also touched upon feelings regarding their occupation or, in cases, the lack of thereof, as well as workplace relationships and the individual chances of finding employment. In the final section, I focused on freetime activities and on the intensity of friendships created during the school years. I believed it to be important to survey how the social networks of a socially disadvantaged individual differ from the social networks of an ordinary adult in Nyíregyháza.

Results of my study: the nature of supportive social relationships is undergoing a change in the case of the socially disadvantaged; close and intense relationships (family members) are starting to become less and less able to provide support, thus they are not the primary support for social integration in these cases.

Keywords: egocentrikus network, integration family relationships, friendships, solidarity

azonos kérdőívvel próbálja feltárni a változásokat, úgy, hogy a kérdezők ugyanazokat a háztartásokat keresik fel meghatározott idöközönként. 


\section{Bevezetés}

„Nem jó az embernek egyedül lenni” (I. MÓZES, 2:18) - ez a Bibliából származó több ezer éves kijelentés ma is aktuális. Az emberi élet változások sorozata, de az a törekvés, hogy mindannyian emberek közé vágyunk, velük szeretnénk kommunikálni és interakcióba lépni, állandó.

Egy jól müködő társadalom egyik legfontosabb értéke a pozitív társas kapcsolatok rendszere, hiszen ez az alapja bármilyen közösségnek, szervezetnek, csoportnak, osztálynak vagy kisebb-nagyobb összejövetelnek. Ugyanakkor természetes védelmi hálót nyújt a benne lévő személyeknek, tagoknak. Az ember belső késztetése (szükséglete), hogy társaságban, közösségben éljen, hiszen „az ember társas lény", mint mondják... Biztosan kijelenthetjük, hogy a társadalom elsőszámú közössége a család. A szocializáció elsődleges színtere, hiszen a társadalomban az emberek túlnyomó többségét a születésétől a haláláig családi kapcsolatok veszik körül. Ez az alapja és meghatározója a társadalomban zajló pozitív és negatív emberi kapcsolatoknak.

Jelentős változások mentek végbe a társadalomban, ezen belül pedig a kisebb-nagyobb csoportokban, közösségekben. Az informális csoportok jelentősége csökkent ezzel szemben nagymértékben megnőtt a formálisaké. A különböző közösségi alkalmak szervezésében, kapcsolatteremtésben nehézségekkel kellett szembenézniük a szervezőknek. Ez azért is van így, mert a rohanó világban egyre nehezebben lehetett és lehet megszervezni egy csoportot, ennek okán a csoportokkal végzett munkaforma nagy jelentőséget kapott a szociális munkában is (Soós, 2005). Magyarországon a családszerkezet felbomlásával, a nők munkába állásával az úgynevezett Arany János-féle Családi kör modellje megváltozott. Sok helyen a nők szerepe hangsúlyosabb lett, a nők vették át az irányító, családösszetartó szerepet. Ez főleg érzékelhető volt az első világháború időszakában (Bagyinszki, 2007).

A családszerkezet azonban ma is jelentős változáson megy át. Magyarország népességének száma 1980-tól folyamatosan csökken, viszont a globális világban a túlnépesedés a jellemző. „A KSH legfrissebb adatai szerint 2010 végére a népesség száma tízmillió alá esett. Ez azt jelenti, hogy az elmúlt 30 év alatt több mint 700 ezerrel csökkent Magyarország lakossága. E kedvezőtlen változással párhuzamosan csökkent a házasságok, és emelkedett a válások száma. Mind a házasságkötések, mind pedig az első gyermek vállalása fokozatosan kitolódik a későbbi életkorra. Ugyanakkor emelkedik az együttélések és az ilyen párkapcsolatból született gyermekek száma. Mindez a család intézményének válságát jelzi." (Batár, 2011: 704). Ez negatív hatással van a magyar társadalom müködésére, hiszen a probléma velejárója, hogy a szolidaritás erőssége jelentősen csökken. 
Fran Newman (2004) is rámutatott arra, hogy a „megbomlott harmóniájú” családokban nevelkedő gyermekek valamennyien szenvednek. A családi élet okozója, egyben színtere is a megélt kríziseknek, mint a családon belüli erőszak, egy közeli hozzátartozó halála vagy súlyos, életminőséget megváltoztató betegsége. Ugyanakkor a szülők válása, alkoholizmusa, a rossz szociális helyzet, a negatív társadalmi megítélés, kirekesztés mind komoly hatással vannak a gyermekek jövőbeni fejlődésére és magatartására.

„A minősítő, szociális válaszelmélet (labelling theory) képviselői abból indulnak ki, hogy az ember - lévén nem tárgy - magatartásával válaszol az ôt érő kényszerekre, impulzusokra, a szociális kontroll (intézményi, családi, szomszédsági, stb.) olyan torzulásaira, amelyek nagyon sok embert indítanak el és erősítenek meg a deviáns karrier útján... A családot interaktív közösségnek tekintem. Belső világában, intimszférájában és a közvetlen vagy távolabbi kapcsolatrendszerben egyaránt. Itt tanulja meg az ember, hogy mit jelent szeretetet, gyengédséget, törődést, menedéket adni, kapni, itt lesheti el az egymáshoz való igazodás fortélyait, a lehetséges konfliktusok humánus kezelését, jó esetben a közös élet felelősségét, a szolidaritást, az önzetlenség ízét, szépségét” (Hanák 1998: 230).

\section{Általában az egyéni kapcsolati hálóról}

A kapcsolati hálókban lévő kötéseknek két nagy típusát különböztethetjük meg: erős illetve gyenge kötéseket (Granovetter 1973). „Az erős kötésekhez soroljuk általában a közeli családtagokat (szülők, házastárs, gyerekek, testvérek) illetve a barátokat. Azok, akik sok erős kötéssel rendelkeznek, sürü kapcsolati hálót mondhatnak magukénak, ahol szinte mindenki ismer mindenkit. Ezek a hálók multiplexek, azaz egy-egy kapcsolat többféle szerepet is betölt, többféle feladatot is ellát, ezen kívül homofil kapcsolatok jellemzőek, azaz a hálóbeli tagok sok tekintetben hasonlítanak egymásra (pl.nem, kor, iskolai végzettség). Az erős kapcsolatoknak kicsi az úgynevezett híd szerepe, tehát elsősorban a mikrotársadalmi integrációt segítik elő.... A gyenge kötésekhez általánosságban a szomszédokat, ismerősöket, régebbi osztálytársakat, tanárokat stb. soroljuk. A gyenge kötések szerepe a híd funkciójukban áll, ami azt jelenti, hogy ezek a kötések képesek a makrotársadalmi integrációt elősegíteni azáltal, hogy különböző társadalmi csoportokat tudnak összekötni” (Huszti 2012:156).

A természetes szociális védőháló és a támogató rendszerek hatásával illetve a családokra gyakorolt befolyásával már a hetvenes évek óta foglalkozik az amerikai és a nyugat-európai társadalomtudomány. Nemzetközi viszonylatban Fowler s 
Christakis és Fowler ${ }^{2}$ is nagy visszhangot kiváltó közleményükben nem kevesebbet állítottak, mint hogy a boldogság társas kapcsolatok útján terjed. Mivel az ember társas lény, a társadalom nem csak hogy létezik, de a létezése elkerülhetetlen, és minden embert többféle módon befolyásol a társadalom egésze és a hozzá tartozó csoportok és személyek. Ebből következik, hogy az egyének jellemzőinek (például a viselkedésüknek és az egészségüknek) a megértéséhez szükségesek olyan módszerek is, amelyekkel az emberek közötti társas kapcsolatok tanulmányozhatók. Egyik ilyen módszer a társas hálózatok elemzése. Leegyszerüsítve, a hálózatkutatók megkérdezik a vizsgálat résztvevőit, hogy kiket ismernek, majd megállapítják, hogy kik ismerik egymást, és ezzel vizuálisan ábrázolják és menynyiségileg elemzik a személyek közötti és körüli hálózat szövedékét. Christakis és Fowler vizsgálata több szempontból is jól van kivitelezve. Először is, az adatgyüjtéskor nem a boldogság és a társas hálózatok meghatározása volt a cél. Ezért az adatokat nem torzította a kutatók ilyen irányú törekvése, sem a résztvevők törekvése arra, hogy társadalmilag kívánatos válaszokat adjanak (például hogy ne sértsék meg ismerőseiket azzal, hogy nem említik őket, vagy bizonyítsák, hogy olyan emberekkel állnak kapcsolatban, akikkel „,illik”). Amint Utasi 1991-es tanulmányából kiderül, Magyarországon a nyolcvanas években végzett nemzetközi kapcsolatrendszer-vizsgálat adatai szerint erős családi-rokonsági kötelékek segítették a megélhetést, és az egyéni biztonságot. A családi együttmüködés intenzív volt. Összességében a nyolcvanas években az erős kapcsolatokból szőtt hálók segítségével a társadalmi szolidaritás rendkívül jól müködött (Utasi 1991).

„Viszonylag legnagyobb számban a nyolcvanas évek második feléből állnak rendelkezésre kutatási eredmények, és ezek egy része nemzetközi összehasonlításra is lehetőséget nyújtott. Az 1986-as ISSP „,social network”-vizsgálat megállapításai szerint (Utasi, 1990) a projektben részt vevő nyugati országokhoz képest Magyarországon sokkal pregnánsabb volt a családi-rokonsági kötelékek, s általában gyengébb a választáson alapuló kapcsolatok súlya a támogatási hálózatokon belül” (Angelusz és Tardos 1998:239).

A nyolcvanas évek második felének vizsgálati eredményei tehát (ISSP 'social network' - 1986 Utasi) azt mutatták, hogy ,,a családi és rokonsági szálak nagyobb arányát regisztrálhattuk hazai körülmények közt, míg az egyéb kapcsolatokon belül a munkahellyel összefüggő, munkatársi viszonylatok nagyobb, az intézményeken kívüli baráti, ismerősi jellegü kontaktusok alacsonyabb arányát állapítottuk meg” (Angelusz és Tardos 1998).

\footnotetext{
${ }^{2}$ Christakis, Nicholas A. és Fowler, James H. (2010). Kapcsolatok hálójában: mire képesek a közösségi hálózatok, és hogyan alakítják sorsunkat? Bőgel György, Csermely Péter, Lovrics László kommentjeivel, ford. Rohonyi András és Rozsnyói Pál, Budapest: Typotex.
} 
A rendszerváltást követő kutatásokból kiderül, a magasabb státusú társadalmi rétegek körében felerősödött az individualizálódás. A gazdagodás vágya lazította a kapcsolatokat. Ekkor már nagymértékben fokozódott a gazdasági-vagyoni egyenlőtlenség, eközben a jómódúak, ezen belül pedig a vállalkozók kapcsolati erőforrásuk segítségével, a család és a rokonok megtakarításaiból, bizalmi és kapcsolati tőkéjük felhasználásával tudtak érvényesülni (Utasi, 2002).

A TÁRKI Háztartás Monitor kutatása a kutatási témák tekintetében a Magyar Háztartás Panel utódja. A Háztartás Monitor vizsgálat sorozat 1998-ban kezdődött el, miután a Magyar Háztartás Panel (1992-1997) véget ért. A Háztartás Monitor longitudinális keresztmetszeti háztartásvizsgálat. A vizsgálat központjában a munkaerőpiac és a jövedelmek témái állnak, de emellett a fogyasztás, a vagyon, a megtakarítás, a gazdasági várakozások, attitüdök, a társas kapcsolatok, valamint a politikai pártválasztás és a vallási hovatartozás is a vizsgálat tárgya volt. A kutatást több kormányzati és állami szerv valamint magán intézmény támogatta kutatási megrendelésével (www 1).

Az Utasi 2001-es, a család integráló erejének trendjét vázoló kutatásának fő kérdése, hogy bizonyos válsághelyzetekben a válaszadók kinek a szolidaritására támaszkodtak elsődlegesen másfél évtizeddel korábban (1986-ban), és hasonló válsághelyzetben melyik kapcsolatuk támogatására, szolidaritására számítanak 2001-ben.

A két vizsgálat egybehangzóan jelzi, hogy a tradicionális házassági, családi kapcsolatban élők aránya mintegy 14-18 százalékkal csökkent az elmúlt másfél évtized alatt. A személyes találkozás korábbi intenzitása mellett a szolidaritásakciók feltételeiben a kedvezőbb változást a kapcsolattartás közvetett eszközének, a telefonnak az elterjedése jelenti. Megállapítható, hogy a telefonkapcsolat hatása persze korántsem azonos a közvetlen találkozással, ám a szolidaritásiakciók, a rendkívüli helyzetekben történő családi segítségnyújtás szempontjából jelentősége nagy (Utasi 2002). További kutatás mutatott rá arra, hogy a családtagok és a baráti kör nyújtotta biztos légkör elengedhetetlen feltétele az elégedettség érzésének (Utasi 2008).

\section{A kutatás célja és módszere}

A természetes védelmi háló müködésére irányuló kutatások Nyíregyházán már 1995-ben elkezdődtek kérdőíves felméréssel. A vizsgálatok arra irányultak, hogy létezik-e egyáltalán olyan rendszer, amelyet a szükségleteket szenvedö lakosok segítségül tudnak hívni. Milyen mértékben számíthatnak a családjukra, barátaikra, szomszédságukra, munkatársaikra a különféle problémáik megoldásában (Fábián 1997). A kutatások tovább folytatódtak a természetes-támogató rendsze- 
rek vonatkozásában, a társadalom helyzetére és az egyéni szükségletek kielégítése során történő támogató rendszerre fókuszálva (Nyírcsák, 1997). A 2008-ban indult Nyíregyháza Város Életminősége címü kutatássorozat átfogóan vizsgálja, hogy egy nyíregyházi polgár mennyire integrálódott be a helyi közösségbe és milyen kapcsolati potenciálokkal rendelkezik (Huszti, 2008). „Az elmúlt négy évtizedben a különböző típusú névgenerátorok voltak a legfontosabb mérési módszerek, melyek közelebb vitték a kutatókat az egocentrikus kapcsolati háló megismeréséhez. Az egocentrikus kapcsolati háló felmérésének két leggyakrabban alkalmazott, legnépszerübb módszere a Wellman, Fischer, Burt, Marsden neveihez köthető névgenerátor, valamint az elsősorban Lin és Dumin nevével fémjelzett pozíció generátor. Mindkét módszer elsődleges célja, hogy az egyéni kapcsolatrendszer társas támogatását és a kapcsolatok által elérhető erőforrásokat próbálja feltárni” (Huszti 2013:80).

\section{Módszer}

A kutatásom a korábbi kérdőíves felmérésekből kiindulva egy szükebb társadalmi réteget céloz meg. Mivel hasonló felmérések nem készültek korábban interjú módszerrel, ezért kevés ismerettel rendelkeztem a vizsgálni kívánt problémák feltárásához. Feltáró kutatásomban tehát módszerként a nem véletlen mintavételi technikák közül az önkényes mintavételt tartottam célravezetőnek. A résztvevő személyek kiválasztásában a HUMAN-NET Alapítvány munkatársai voltak a segítségemre. Biztosítottak számomra egy külön szobát, ahol a megkérdezettel nyugodt körülmények között tudtam beszélgetni, és nem volt semmiféle zavaró tényezö. Az interjúkat 2011. július 4-től -2011. augusztus 17-ig személyesen készítettem el és diktafonra rögzítettem. Minden megkérdezett 18 évesnél idősebb volt. A válaszadás önkéntes, a diktafonra történő rögzítés előzetes engedélykéréssel valósult meg, az anonimitás biztosítva volt, teljes nevet illetve lakcímet egyik esetben sem kértem. A vizsgálat során az elemszámom összesen 10 fö volt.

A természetes védőháló-kutatás során a megkérdezettekből hat ember nyíregyházi (belvárosi) lakos, két megkérdezett cigánytelepen él, egy Nagyszálláson egy pedig Nyírjesen. A Huszártelep egykor laktanyaként funkcionált, mára jellegét tekintve a nyugati nagyvárosok etnikai jellegü perem-gettóihoz hasonlít (www 2). A telepre jellemző az épületek lelakottsága, romossága. Az itt készült interjúkat az egykori általános iskolában tudtam elkészíteni, az épület mára már „Huszárvár Szocio-Kulturális Szolgáltató Központ” néven működik, ahol a családsegítő szolgálat, a különböző közösségi ellátások, illetve a gyermekek nyári étkeztetése zajlik. Az itt készült interjúim sok információval bírnak a kutatás témáját illetően. A nagyszállási és nyírjesi lakosok interjúinak elkészítésénél a HUMAN-NET Alapítvány munkatársai segítettek a körülmények megteremtésében: a tanyagondnoki szolgálat autója kivitt a helyszínre és személyesen, a lakókörnyezetüket megfigyelve tudtam megkérdezni őket. 
Az interjúk félig strukturáltak, mindenkitől ugyanazt kérdeztem, viszont a témáról szabadon beszélhettek, illetve idő közben felmerülö vagy a témához jobban kapcsolódó új kérdések is bekerültek a repertoárba. A beszélgetés első részében úgynevezett „,ráhangoló”, bevezető kérdéseket alkalmaztam, pl. hogyan szólíthatom, mekkora a családja, meséljen a gyermekkoráról. A bizalom kiépítése nagyon fontos volt számomra. Ahhoz, hogy érzéseiket őszintén megjelenítsék és kifejezzék nekem. A bevezető részben és a kérdések döntő többségében nyílt kérdéseket használtam. A kérdések számát tekintve körülbelül harmincat tettem fel, de ez minden egyes interjú alanynál változott, hiszen egy-egy témában, ami öt nagyon foglalkoztatta, ott több kérdést alkalmaztam. Ezek után következtek azok a kérdések, melyek a rokoni, baráti találkozások gyakoriságára, a foglalkozásra, klub vagy szervezeti tagságra irányultak. A munkahely meglétével vagy ennek hiányával kapcsolatos érzések, a munkahelyi kapcsolatok, munkahelyszerzés egyéni lehetőségei következtek. Az utolsó blokkban pedig a szabadidős tevékenységekre, az iskolai végzettségre, illetve az iskolában kötött baráti kapcsolatok intenzitására, idegen nyelvi tudás felmérésére, és végül az életcélokra és a jövőképre fókuszáltak a kérdéseim.

Célom volt, hogy a közösségeken belüli személyes kapcsolatokat, illetve a segítő kapcsolatok hálózatát vizsgáljam. Milyen kapcsolati hálóval rendelkeznek az alapítványhoz forduló, problémákkal küzdő emberek? A társas támogatás néhány formája a hátrányos helyzetben élő emberek esetében; a vizsgálat során az egyén szubjektív érzéseit, attitüdjeit kerestem a segítő-támogató viszonyokban, azt, hogy az egyén társadalmi struktúrában elfoglalt helye (életkor, lakhely, foglalkozása, jövedelmi viszonyai) hogyan alakítják kapcsolatrendszerét. Továbbá, hogy a „segítőnek” olyan információkat nyújtsak, amelyekkel a klienskörük kapcsolati hálóját erösíteni tudják. Fontosnak tartottam megvizsgálni, hogy egy szociálisan hátrányos helyzetben élő ember kapcsolati hálója mennyiben tér el az átlagos nyíregyházi felnőttekétől. A munkámban megjelennek szubjektív elemek, hiszen ebben a témában hasonló jellegü felmérések ritkák a segítő szakmában.

\section{A kutatás eredményei}

Mark Granovetter vezette be a gyenge és az erős kötések megülönböztetését: két aktor közötti kötés erősségét az azt jellemző érzelmi töltés, a rá fordított idő és a kölcsönös szolgáltatások cseréje határozza meg. Megállapítja, hogy az egyént körülvevő emberek szoros kötésekkel kapcsolódnak az egóhoz, míg a gyenge kötések gyakran nyúlnak a csoporton kívülre: ezek a messzebbre nyúló gyenge kötések gyakran szolgálnak hídként, nemcsak az ego és ismerőse között, de raj- 
tuk keresztül az őket körülvevő közeli barátok hálója között (Granovetter 1973). A következő részben jellemzően az erős kapcsolatokkal (úgymint szülő, gyermek stb.) foglalkozok.

\section{Gyermekkor}

A kutatásomban résztvevő, alapítványhoz forduló emberek vizsgálatakor többségüknél azt tapasztaltam, hogy rossz gyermekkoruk volt. A legközelebbi hozzátartozójukkal (anya, apa, testvér) sem volt meg az a pozitív kapcsolat-rendszer, amelyet az interjúk elkészítése előtt feltételeztem. A család pedig az elsődleges csoport, amely a társadalmi támogatórendszer lényegét képezi és a benne nevelkedő egyén támaszául szolgál, illetve az ember biológiai létezésének legfőbb színterét jelenti, és a társadalmi létezés első szervezeti formáját (Bánlaky 2004). A megkérdezettek többsége Nyíregyházán született és itt is nevelkedett, ahogy felmenőik is. Szüleik legmagasabb iskolai végzettségét tekintve jellemzően szakmunkás bizonyítvánnyal rendelkeznek. A megkérdezettek a válás, az egyik szülő halála, vagy nevelőszülőnél való nevelkedés miatt csonka családban nőttek fel. A természetes védelmi háló legerősebb eleme a család, az alapítványhoz forduló megkérdezetteknél ez a segítő kapcsolati háló nagymértékben sérült. A kapcsolati háló vizsgálatok rámutattak arra, hogy a gazdasági egyenlőtlenségeket fokozó piacgazdaságban az egyén nem számíthat közvetlen kapcsolataira, főként családja és rokoni támogatására, szolidaritására és amennyiben a szervezetek, intézmények sem segítik vagyis nem müködik a kompenzáló társadalmi szolidaritás, akkor a társadalom jelentős rész izolálódik, perifériára szorul és ezáltal csökken a társadalmi integráció (Utasi 2002). A családi szolidaritásra, elsősorban a párkapcsolatukra támaszkodhatnak, a megkérdezettek közül már senki nem él házastársi kapcsolatban. Többségük válás, illetve a házastárs halála miatt élettársi kapcsolatban él. Az interjúk felvétele során többnyire azt éreztem, hogy emocionálisan labilisak. A válaszadókról elmondható, hogy nem érzik a családtól származó szolidaritást, és ennek hiányában nehezen vagy egyáltalán nem képesek integrálódni a mikrotársadalomba. A makrotársadalmi szolidaritás csak akkor képes egymaga is eredményesen gátolni a versenyre képteleneket, a versenyből kimaradók izolálódását, ha a társadalmi szolidaritási akciókhoz kellő mértékü anyagi forrásokkal, hatalommal és akarattal rendelkeznek (Utasi, 2002).

„Nem jó gyermekkorom volt, apukám meghalt még ’71-be, másfél éves voltam, mikor meghalt, anyukám egyedül nevelt fel bennünket. Hatan vagyunk testvérek, abból már most kettő elhunyt. Most halt meg az édesanyám a múlt hónapba. A gyermekkorom nem volt olyan híres, öt osztályt végeztem, szegények voltunk. 
Nehezen jártunk iskolába is, anyukám nehezen gondoskodott rólunk." (Nagyszállási középkorú asszony)

„Intézetbe nevelkedtem, jelenleg Nyíregyházán lakok a Guszev-ben, nevelőszülökhöz kerültem ötéves koromban, végig egy nevelöszülőnél nevelkedtem, gyermekként is Nyíregyházán laktam. Tudomásom szerint van négy húgom, ebből kettőt láttam csak, de nem tartjuk egymással a kapcsolatot. Régen úgy találkoztunk, hogy az intézet csinált egy-két napos tábort és ott tudtunk a testvéreimmel találkozni. Semmit sem tudok róluk, megszakadt velük a kapcsolatom. Gondoltam, hogy Vöröskereszten vagy a Periférián keresztül megkerestetem őket, de valahogy nem jutottam még el odáig." (Huszártelepi középkorú férfi)

„Apukám jegyellenőr volt, anyukám pedig mindig mást csinált, irodában takarított, ládát szegelt, sok mindent csinált. ... Apukám, anyukám ivott és ebből voltak viták. Kiskoromról ezek a rossz emlékek megmaradtak." (Nyíregyházi 26 éves nő)

\section{Családi kapcsolatok}

Ez egy következö kapcsolati háló szint: a rokonok (közeli, távoli). A családi, rokonsági kapcsolatok alakulását tekintve, említést tettem róla, hogy az egyre növekvő válások száma, a házasságkötések csökkenése a család, mint intézmény válságát jelzi Magyarországon.

Kutatásom alapján megállapíthatom, hogy ez az általam meginterjúvolt alanyoknál sincs másképp, sőt még erőteljesebben jelentkezik a probléma. Témám szempontjából kiemelten figyelemre méltó, hogy meglehetősen gyakori a családi kapcsolatok megszakadása, az anyagi problémák megjelenésekor a rokonok is eltávolodnak a segítségre szoruló családtagjuktól. Az elszigetelt családtagnak legtöbbször nincs módja segítséget kérni. Mivel lehetőségei nem engedik meg, hogy felhívja telefonon vagy személyesen megkeresse azt az embert, akitől elsődlegesen remélhetne anyagi vagy érzelmi támogatást. Véleményem szerint ez is közrejátszhat az alapítványhoz fordulók számának növekedésében. Több válaszadó hangsúlyozta, hogy az egyéni érdekek előtérbe helyezése, tehát az individualizálódás miatt, nem számíthatnak segítségre már sokszor a rokonoktól sem. A rég nem látott rokonok mellett a meglévő rokoni találkozások a havi rendszerességet sem érik el esetükben, körükben a féléves-éves gyakoriság a jellemzö. A közvetlen közösségi kapcsolatokból származó családi-rokoni szolidaritás nélkülözhetetlen nehéz élethelyzetek, különösen a hirtelen adódó problémák megoldásához. A szociológusok, demográfusok vizsgálati adatai e tekin- 
tetben a családi kapcsolatokban bekövetkezett változásokra hívják fel a figyelmet. Az egyéni célok, érdekek közösség elé helyezése elsősorban a család magját jelentő párkapcsolati együttélési formákat módosítja. Növekszik a függetlenségvágy, autonómiaigény, mind többen kívánják az individuális igényeiket elötérbe állító önmegvalósító életet élni (Utasi 2002).

Azt gondolom, hogy az általam megkérdezettek esetében fontos szükséglethiányként jelentkezik ez a probléma: az elkeseredettség érzése tükröződött az arcukon, mikor erröl beszéltek. Igény pedig lenne az irányukból, hiszen többen is említették, hogy szeretnék felkeresni rég nem látott családtagjaikat. A gyengék, tehetetlenek, forráshiányosak kimaradnak a közösségi szolidaritáshálóból, elesnek az esetleges lehetőségektől. Utasiék korábbi adatok (ISSP, 2001) alapján megállapították, hogy akinek az erős kapcsolataik is hiányosak, vagy egyáltalán nem is léteznek, alig találnak kapcsolatokat más közösségekben, azaz gyenge kapcsolataikat sem tudják úgy építeni, mint azok, akik rendelkeznek erős kapcsolatokkal. A társadalmi integráció ilyen mértékủ reménytelensége esetén a társadalom érintett tagjai visszahúzódással válaszolnak (Utasi 2006).

„...Édesanyám újra házasságot kötött, ebből lett három testvérem. Nem tartom a kapcsolatot testvéreimmel sem, édesanyámmal sem, féltestvéreimmel sem. Édesanyám jelenleg az egyik féltestvéremmel él. Kisebbik bátyámat szeretném felkeresni, már próbálkoztam a Vöröskereszt által, de nem jártam sikerrel. Nagyobbik testvéremmel tartom a kapcsolatot. Az anyagi lehetősége nem engedi meg az embernek azt, hogy telefonáljak. ...27.000 Ft a bevételem és akkor ebből kell megélnem, csak a szociális segélyt kapom.” (Belvárosi középkorú nő)

„...A fiam nem is tudja, hogy ki az apja. Soha nem is találkoztunk, tudom, hol lakik, itt Nagycserkeszen, de nem bolygatom. ...Nagyban hozzájárul az életvitel meg a felelőtlenség, az ember fiatalon nem gondolkodik, csak cselekszik, majd utána gondolkodik, hogy mi van... ne félj, most 42 éves fejjel nem csinálnám azt, másképp gondolkodnék, csak a festészetbe ölném minden energiámat." (Huszártelepi középkorú férfi) 


\section{Baráti kapcsolatok}

A családtagokon, rokonokon kívül a baráti kapcsolatok biztosítják a legjelentősebb védelmi hálót. A baráti kapcsolatok számának alakulásáról több helyi kutatás is készült 2010-ben, 2012-ben illetve 2015-ben is. ${ }^{3}$ Azt a kérdést tehát, hogy „Hány barátja van Önnek?” több hazai kutatásban is alkalmazták már. Ha az országos tendenciákat megfigyeljük, már a tíznél több baráttal bírók aránya is csökken. Az adatok arra utalnak, hogy hazánkban egyre csökken a sok baráttal rendelkezők aránya, mely tendencia nem egyedülálló, hiszen a nyugati országokban is az jellemző, hogy egyre inkább beszükülni látszik az emberek személyes kapcsolati hálója (Angelusz-Tardos, 1998).

$\mathrm{Az}$ alapítványhoz forduló megkérdezettek körében igen nagy azoknak a száma, akik egy baráttal sem rendelkeznek. Föként arra kerestem a választ, hogy az anyagi helyzet romlásával mennyiben változik az esetlegesen meglévő baráti kapcsolat erőssége, intenzitása. Azt tapasztaltam, hogy az előzőleg sok baráttal rendelkező emberek, az anyagi helyzet romlását követően egyre kevesebb baráttal, illetve a meglévő baráti kapcsolatok meggyengülésével, nem ritkán elvesztésével számolnak. Emellett a tanyán megkérdezett személyeknél azt tapasztaltam, hogy intenzívebben segítik egymást a barátok és a rokonok egyaránt. Az anyagi javakkal megvalósuló segítségnyújtásról feltételezhetjük, hogy a fiatalabb és jómódú rétegek körében az átlagosnál magasabb lehet az esélye a segítségnyújtásnak. A legrosszabb élethelyzetben élők azok, akikre a legjellemzőbb az, hogy soha nem találkoznak barátaikkal. A rossz életfeltételek általában is hozzájárulnak a kapcsolatok beszüküléséhez (Utasi, 2008).

A nyíregyházi panelkutatás mindhárom vizsgált évében érvényben maradt a negatív irányú összefüggés a kor és a barátok átlagos száma között, azaz minél idősebb valaki, annál kevesebb baráttal rendelkezik. Ez a tendencia egyébként hazai viszonylatban is így jelentkezik, az idősebb korcsoportok a társadalom izolált csoportjaihoz sorolhatók. Ez viszont nem törvényszerü, mert vannak olyan országok, ahol minél idősebb valaki, annál nagyobb kapcsolathálóval bír (Pl. Svájc, Kanada) (Huszti 2013).

\footnotetext{
${ }^{3}$ Huszti Éva: Társas kapcsolatok Nyíregyházán. Szabolcs-Szatmár-Beregi Szemle 4. p. 590-606., 2009.

Huszti Éva: Mint pók a hálóját. Az észak-alföldi régió ifjúsági szervezeteinek kapcsolati hálója. In: Az Észak-alföldi ifjúsági szervezetek kapcsolati hálója egy szociológiai kutatás mentén. Nyíregyháza, Kalamáris Egyesület, 2009.

Huszti Éva: „Jönnek is a rokonok, ismer_sök sorra...” Társas kapcsolatok Nyíregyházán. In: A Nemzetközi III. Nyíregyházi Doktorandusz (PhD/DLA) Konferencia Kiadványa. Nyíregyháza, Szent Atanáz Görög Katolikus Hittudományi F_iskola. p. 23-28., 2010.
} 
Az általam megkérdezettek esetében is a kevesebb erőforrással rendelkező rétegek kimaradnak az erős kapcsolatok által nyújtott segítségből, mivel a közvetlen környezete (lakókörnyezete) sem rendelkezik erős anyagi forrásokkal. A válaszadók és az általuk legszorosabbnak mondott baráti kapcsolatuk iskolai végzettsége között összefüggést találtam, hiszen, mindegyikük ugyanolyan iskolai végzettséggel rendelkezett, mint a barátjuk ${ }^{4}$. Az esetükben ez igen alacsony iskolai végzettséget jelent és a kapcsolati tőke hiányának a megemlítése esetükben igen nagy fontosságú. A helyi panelkutatás arra is rámutatott, hogy a végzettség és a barátok átlagos száma között egyenes arányú összefüggés jellemző, minél alacsonyabb valakinek az iskolai végzettsége, annál kevesebb barátja van (Huszti, 2013).

„Nincs barátom, senki, akinek azt mondanám, hogy ez és ez a problémám, hogy segítsél megoldani... Az a baj, hogy olyan ritka a barátság, én már nem is hiszek benne, azért nincsenek barátaim, mert én most egy sikertelen ember vagyok, nincs, ugye, munkahelyem, nincs semmi, amit felmutathatok és a sikertelen embereket elkerülik. Nem szeretnek egy sikertelen emberrel együtt lenni. Ezt éreztem, bár senki nem jelentette ki." (Belvárosi 46 éves nő)

„Voltak barátaim, addig, amíg az embernek volt pénze meg mindene, úgy, addig müködött. Szerintem igaz barát ritka, mint a fehér holló, nekem nem volt. Mert ha lett volna, akkor ebben a rossz helyzetemben biztos kitartanak mellettem." (Középkorú férfi)

Az interneten, a „hálón” keresztüli kapcsolattartásra is kitértem a baráti kapcsolatok vizsgálata során, itt is igen csak meglepődve tapasztaltam, hogy a fiatal generáción kívül a középkorú réteg is intenzíven tartja a kapcsolatot a barátaival. Az általam megkérdezettek egyike sem rendelkezik diplomával, legmagasabb végzettség szakmunkásképző.

„Egy barátom van és ő egy külföldi fiú, akit a facebook-on keresztül ismertem meg. Személyesen még nem találkoztunk, csak web kamerán láttuk egymást. Amikor apukám meghalt, akkor ö volt a lelki támaszom, minden nap beszélünk.” (27 éves nyíregyházi nő)

\footnotetext{
${ }^{4}$ Homofília elve: „A homofilia, azaz a hasonlók választása nemcsak a gyermekkori, hanem a felnöttkori választott hálózatoknak is alapvetö jellemzője: a hálózati alanyok szivesen lépnek kapcsolatba olyanokkal, akik hozzájuk hasonló tulajdonságokkal rendelkeznek olyan jellemzök tekintetében, mint pl.: a kor, a nem, az etnikum vagy az iskolai végzettség." (Kürtösi, 2004)
} 
„Személyesen sok embert ismerek, de nagyon kevés van köztük, akiket barátnak tartok, olyan kb. 5 föt. Munkám által ismertem meg öket, illetve az egyikkel gyerekkori barátok vagyunk. Egy kivétellel mindegyik nyíregyházi lakos. Közösségi oldalon regisztráltam, ott a vidéki haverral szoktam beszélni, aki elköltözött, egy vidéki húsdepóba dolgozik." (34 éves nyíregyházi férfi)

\section{Lakókörnyezet, szomszédsági kapcsolatok}

Ez már egy másik szint az egyéni kapcsolati hálóban. A szomszédokat jellemzöen a gyenge kötések közé szokták sorolni. A gyenge kapcsolatok sürúsége általában a problémamegoldást és a változásokkal kapcsolatos felkészültség mértékét növeli (Granovetter 1973).

A lakókörnyezet hatása jelentős a megkérdezetteknél, hiszen ha azonnali segítségre van szükségük, akkor a jó szomszédi viszony nagyban segíti a krízisben lévő egyént problémájának - elsősorban rövidtávú - kezelésében. Gondolok itt különbözö használati cikkek kölcsönkérésére a mindennapok során, amelyek hiánya igencsak megnehezítheti a boldogulásukat. De mindemellett maga a tudat, hogy olyan ember él „mellettem”, akire számíthatok, ha bajban vagyok, ez jelentős, hiszen az alanyok többsége munkanélküli, alig mozdul ki otthonából, lakókörnyezetéből. Úgynevezett helyi támaszt, biztonságot jelenthet számára a szomszédokkal tartott pozitív társas kapcsolat. A tanyavilágban élőknél rendkívül erős ez a fajta védelmi háló. Az itt élőknél a szomszéd sokszor egyben rokon is. Elmondásuk szerint a segítséget adók sincsenek sokkal jobb anyagi helyzetben, mégis jellemző ez a fajta szolidaritási csere köztük, hiszen ez esetükben nem csak egyoldalú, lehetőségeikhez mérten reciprokszerüen müködik.

„Gyakran találkozok szomszédjaimmal. Mán ha egy-két napot nem látjuk, akkor vagy csöngetünk be hozzá vagy menyünk megnézni, hogy mi van vele, mér nem mozog, mér nem jön a bótba. ...Mikor disznót vágnak, ideállít akkora pakkal, hogy a fagyasztót ki kell üríteni. ... Egyébként a szabolcsi ember mindég ilyen vót, legalábbis akit én ismerek, az nem hagyta, hogy a másik nélkülözzön, ha neki egy falat kenyér vót, azt is megfelezte, ha látta, hogy a másiknak nincs. Az nem ember, aki ezt nem teszi meg, legalább is az én szemembe nem." (Nyírjes tanyán élö asszony)

„A szomszédokkal nagyon jó a viszonyom, ha elfogy a só, cukor adunk egymásnak, sőt még pénzt is adunk kölcsön egymásnak. Minden nap találkozunk itt a tanyán. ... Most vasárnap úgy járt szegény unokanővérem, hogy félig kész vót a befözéshez való uborka, mán berakta az üvegbe, kész vót, amit rá kell tenni az a 
lé, keresi a babérlevelet, nincs babérlevél, kiabál itt a kerítésen: Margitkám, ha Istent ismersz, adjál nekem babérlevelet. Mondom, várjál, felkutatom a szekrényt, nem tudom van-e. Két csomaggal találtam, odaadtam neki, úgy megörült neki, mán másnap hozta. ...Ez nem csak a rokonokkal van így, hanem a szomszédokkal, barátokkal is." (Nagyszállási középkorú asszony)

A megkérdezett városi lakosság körében már nem mondható el ugyanez. Itt azt tapasztaltam, hogy bár néha-néha kérnek segítséget a közvetlen szomszédoktól, például egy panelház esetében, viszont itt nem olyan gyakori az ilyenfajta segítségkérés. Már a kommunikáció is kevesebb köztük, mint a tanyavilágban.

„Én panelban lakom, minimálisan beszélek szomszédjaimmal. Segítséget nem kérek tőlük, köszönő viszonyban vagyunk.” (Belvárosi középkorú férfi)

„Bérházban lakom, van 12 család, abból négy köszön! Ilyen magukba zárt, elfojtott életet élnek. Én, ahogy ide kerültem már ezt tapasztaltam, szerintem ebbe a munkanélküliség is közrejátszik, hogy nem tud elhelyezkedni. ... Vannak családon belül is ilyen emberek, járkálnak egymáshoz a családok, vagy egy olyan értelmetlen dolog, hogy jön például haza a bótból és neki van főznivalója, a másiknak meg nincs, és akkor megy a nagy hangzavar. Rákiabál, hogy milyen jól megy a dógodnak, nincs itthol a férjed, miből van neked ez meg amaz, és akkor elhordják egymást a sárga födig." (Huszártelepi középkorú férfi)

\section{A munkanélküliség hatása az egyéni kapcsolati hálóra}

Az alapítványhoz fordulók egyik legnagyobb problémája a munkanélküliség. Emellett az adósság is kiemelt fontossággal bír, bár a kutatásom erre a témakörre külön nem terjed ki. A megkérdezettek több mint fele munkanélküli. Ezt a kérdést abban az aspektusban próbáltam megközelíteni, hogy milyen hatást gyakorol a segítséget kérőre ez a probléma emocionálisan, illetve milyen hatással van a kapcsolati hálójára. Az emberek számára a munka tehát nem egyszerüen jövedelemszerzési tevékenység, hanem szociális jelentősége van: a munkavégzés és intézményei az élet egészének legalapvetőbb szervezői közé tartoznak a modern társadalmakban. Ezért a munkanélküliek sokkal alapvetőbb dolgoktól vannak megfosztva, mint a munka-jövedelemtől, amikor nincs munkahelyük. A megváltozott élethelyzet hatással van az emberek egészségi állapotára, önértékelésére, társas kapcsolataira és a társadalmi- közösségi aktivitásra (Kucsber 2012). Azt 
tapasztaltam, hogy olyan erős energiaráfordítással próbálják keresni a munkát, amennyire csak lehetőségük engedi, akár feketemunkát is vállalnak. Sajnos a feketemunka regionális szinten a legmagasabb Nyíregyházán, erről a regionális munkaügyi felügyelőség már többször említést is tett (www 3). A munkanélküliség vizsgálatakor az egyik legjellemzőbb problémát a lehetőség hiányában láttam. Nincsenek meg azok - az átlagember számára természetesnek vett dolgok - , mint pl. a telefonálási lehetőség, az állásinterjún való megjelenés (utazás), az internet - hozzáférés, és épp a legfontosabb, az a kapcsolati háló hiányzik, ami által el tudnának helyezkedni valamilyen munkahelyen. Granovetter tipológiája alapján a gyenge kötéseknek híd szerepe nem valósul meg, így nem tud különböző társadalmi csoportokat összekötni (Huszti, 2009). Ismeretségi körük szük és ezáltal ritkán lépnek interakcióba olyan személyekkel, akik segítséget vagy információt adhatnának munkaszerzéshez. Ez abból áll, hogy ha esetleg van valahol egy megüresedett munkahely, amiröl tájékoztatják a munkanélkülit. Az emberek véleménye szerint egyre ritkább a beajánlás, mindenki félti a saját munkahelyét. Az elkeseredettség mellett olyan negatív önértékelésük van, amely még hátrányosabb helyzetbe hozza őket egy állásinterjún. Azt figyeltem meg, hogy nincs határozott véleményük egy adott témáról, nem nagyon mernek kiállni a saját igazuk mellett, inkább az elfogadást, behódolást vettem észre az esetükben. Mindezek mellett a munkanélkülivé válás az élet során úgynevezett véletlenszerü, vagy akcidentális krízist is kiválthat, melyre jellemző, hogy sérti az önértékelést, megrendíti az önbizalmat és a biztonságérzést, valamint próbára teszi az alkalmazkodókészséget. És ha a baj nem jár egyedül és halmozódik a veszteségélmény, úgy ez sokszorozódik, hatványozott krízissel járhat együtt. Az, hogy a munka elvesztése milyen mértékü krízist eredményez, sok tényező függvénye (Hajduska 2012).

„Mióta nem dolgozok, azóta egyre gyakrabban fordul elö, hogy csak akkor megyek ki, ha ügyet intézek vagy boltba megyek. Most például, ha én ide nem jövök, akkor ma nem lépek ki a ház ajtaján. Tehát tulajdonképpen nem találkozok senkivel. ...Bedolgozok, mint fogtechnikus egy bizonyos helyre, hogyha ott van munka, akkor megyek, ha nincs, akkor otthon vagyok. ... A hétvége és a hétköznap között már nincs is számomra különbség.” (43 éves belvárosi férfi)

A munkanélküliség vizsgálatakor megkérdeztem, milyen módszerekkel keresnek állást. A legtöbben a munkaügyi központot említették, minden érintett regisztrált is a munkaügyi központban. Nagy bizalmatlanságot és dühöt éreztem az irányukból akkor, amikor az intézményről kezdtünk beszélgetni.

„Nincs nekem olyan személy, aki segítséget nyújtott volna eddig, valamilyen állás megszerzésében. Állás megszerzésében a Tüzér utcán és a HUMAN-NET 
Alapítványnál szoktam segítséget kérni, innen kapom az ebédet is. ... A munkaügyi központról, arról meg ne is beszéljünk. Oda csak be kell menni, rosszabb, mint az SZTK, mer reggel beülünk éhen-szomjan és akkor még délbe kiszólnak: elmentünk ebédelni. Itt ülünk éhen-szomjan, nem merünk még vizet se inni, hogy maradjon meg a helyünk, és akkor délutánig még várni kell, hogy visszajöjjenek." (Nyírjesi asszony)

„Rapszodikusan három éve vagyok munkanélküli. Fekete munkáim vannak. Kb. egy hónapja regisztráltam a munkanélküliben. Elvégeztem egy biztonsági őr tanfolyamot. Aztán lett volna állás, csak nem értesítettek időben és arról lecsúsztam. Én vettem észre később, amikor mentem, hogy ki volt plakátozva a falra az álláslehetőség, de akkor már késő volt." (43 éves belvárosi férfi)

Jellemző, hogy igen hosszú ideig nem találnak munkát. A megkérdezettek átlagosan, kisebb-nagyobb megszakításokkal három - négy éve nem találnak tartós munkahelyet. A legsúlyosabb hatás az egyedül élöket éri. Náluk a család hiánya még jobban gyengíti a védelmi hálót.

A munkanélküliséggel összefüggésben rákérdeztem arra, hogy dolgoznának-e külföldön: milyen esélyt látnak arra, hogy esetleg máshol próbáljanak szerencsét? Kitértem arra is, ha nem szeretnének külföldön dolgozni, akkor közre játszik-e döntésükben, hogy a rokonságot, barátokat sajnálnák itt hagyni? Mennyire mérvadó számukra az, hogy az itthoni kapcsolatukat feladva kint próbáljanak szerencsét? Ezeknél a tartósan munkanélküli, saját maguk által esélytelennek ítélt helyzetben nem volt meghatározó tényező az, hogy a környezettel kialakított kapcsolataikat feladják. Ez a fajta védelmi háló olyan gyenge az esetükben, hogy az itthonmaradás választása során ez már nem számít érvnek. Ez jelzi számomra érzelmi kapcsolataik sérülését és viszonyulásukat az őket körülvevő közvetlen környezethez. Többségük egyébként szívesen vállalna külföldön munkát akkor, ha a feltételek biztosítva lennének.

„Ha lehetőségem adódna, dolgoznék külföldön, ha a feltételek biztosítva lennének, P1.: a gyereknek iskola, akkor semmi akadálya. Külföldön többször voltam már Olaszországba, Ausztriába, nem lenne annyira idegen számomra." (41 éves huszártelepi férfi)

„Ha kimentem volna, soha nem jöttem volna vissza. Festőmüvészként nagyobb lett volna az esélyem, szerintem jobban felkaroltak volna.” (Huszártelepi középkorú férfi) 


\section{Vallás}

Az interjúalanyok többségében vallásosnak mondhatók, föként római katolikusok. Magát a templomba járást és a hitet külön kezelték a válaszadók. Inkább jellemző az, hogy nem gyakorolják vallásukat, de az Istenbe vetett hitük megvan. Arra is rákérdeztem, hogy valamilyen vallási közösségbe szoktak-e járni. Feltételeztem, hogy az ilyen közösségek csábítóak lesznek a megkérdezettek számára, hiszen a hitük, elmondásuk szerint, megvan hozzá, az idejükből is kitelik, és azt lehet mondani, hogy ingyenesen tudnak élni ezzel az igen intenzív integrálódási lehetőséggel. Feltevésem nem igazolódott be, hiszen a válaszokból kiderült, hogy többségük érdeklődését ez a lehetőség nem keltette fel.

„...Addig, amíg a gyerekek hittanra jártak, minden vasárnap mentünk, de most, hogy már mind a kettő felnőtt, egyre inkább el van hanyagolódva. Ez akkor derült ki legjobban, mikor az öcsémet temettük és a miatyánkba elakadtam. Elfelejtettem. Tehát annyira ritkán járunk. Temetéskor, keresztelőkor. De Istenbe hinni kell. Másba miben? Miért, ha az embernek valami baja van, akkor mit mond elsősorban? Jaj, Istenem! Az első szava az, igaz? Mert mást nem tud felhozni, hogy jaj, Istenem, segíts! Igaz? Még aki nem vallásos, annak is a szájára jön.” (Nyírjesi asszony)

„Alapjába véve keresztény emberke vagyok, de úgy különösebben csak akkor megyek templomba, ha születik valaki vagy meghal. Nem vagyok egy fanatikus hívő, úgy szoktam mondani se ellene, se mellette.” (61 éves férfi)

\section{Életcélok}

Az interjúkérdések végéhez érve a legfontosabb életcéljaikra kérdeztem rá. Hogyan látják magukat öt év múlva? Hogyan ítélik meg saját helyzetüket, lehetőségeiket? Melyek azok a legfontosabb rövid és hosszú távú célok, amelyeket magukban megfogalmaznak? A válaszadók a kérdés hallatára nagyon elgondolkodtak, sokszor hosszú percekig csendben maradtak. Azt figyeltem meg, hogy akik munkanélküliek, azokon a szorongás és a reménytelenség érzése nagyon erősen dominált. Ez megnyilvánult az arckifejezésükből, gesztusaikból, mimikájukból. Elsősorban gyermekeik támogatásának a gondolata fogalmazódott meg. Az anyagi helyzet javulásának a vágya megfigyelhető volt, nem gazdagságra vagy nagyon magas életszínvonalra vágynak, csupán a mindennapi megélhetés biztonságára. A munkahelyszerzés és a dolgozni akarás motiválja őket. Öt évre 
előre látni - igen nehezen ment számukra, nehezen tudták megfogalmazni, hogy vajon milyen helyen és körülmények között fogják élni az életüket.

„Nem szoktam előre gondolkodni, a mának élek. Nem jó előre belegondolni szerintem, mert az ember, amibe belegondol, és nem úgy jön össze, akkor az egy hatalmas esés, így meg nem." (34 éves férfi)

„Célom innen kiszakadni, gyerekeimnek egy jobb jövőt biztosítani.” (41 éves huszártelepi férfi)

\section{Összegzés}

A családsegítő szolgálatához forduló klienskör egyéni kapcsolati hálóját (egocentrikus network) vizsgáltam, és makrotársadalmi integrációjának mérésére tettem kísérletet félig strukturált interjúk készítésével. Azt vizsgáltam, hogy az egyén társadalmi struktúrában elfoglalt helye (életkor, lakhely, foglalkozás, jövedelmi viszonyok) hogyan alakítják kapcsolatrendszerét. Fontosnak tartottam megvizsgálni, hogy egy szociálisan hátrányos helyzetben élő ember kapcsolati hálója mennyiben tér el az átlagos nyíregyházi felnőttekétől. A társas támogatás alakulásának formája a hátrányos helyzetben élő emberek esetében változó képet mutat, a közeli és erős kapcsolatok (családtagok) kezdenek kifogyni az adható támogatásokból, ezáltal esetükben nem ők jelentik elsősorban a társas integráció útját. Ellentétben egy átlagos nyíregyházi polgárral, aki elsősorban a természetes támogató rendszerét (család, rokonok, barátok, szomszédok) használja a különböző problémáinak a megoldására. Ebből következik, hogy ezeknek a személyeknek olyan segítségre van szüksége a segítőktől, mellyel a kapcsolati hálóját bővíteni tudja. Az egyre kevesebb erőforrással rendelkező személyek kimaradnak az erős kapcsolatok által nyújtott segítségből, mivel a közvetlen környezete sem rendelkezik erőforrássa,1 de hiányosak a hídszerü, gyenge kötések is, melyek az integrációt biztosítják. Ennek a természetes támogató rendszernek a megerősítésével a társadalomba való integráció hatékony formáját érhetjük el. 


\section{Felhasznált irodalom}

1. Angelusz R.-Tardos R. (1998): A kapcsolathálózati erőforrások átrendeződésének tendenciái a kilencvenes években. In.: Társadalmi Riport 1998 Tárki, Budapest.

2. Bagyinszki Z.-Kovács I.-Péntek B. (2007): Idősek Szociális Ellátása. Nemzeti Szakképzési és Felnőttképzési Intézet, Budapest.

3. Bánlaky P. (2004): Családszociológia, Wesley János Lelkészképző Főiskola, Budapest.

4. Batár I. (2011): Család, jövő, társadalom-az MCSNTT 35 éves tevékenysége. Statisztikai Szemle 89.évfolyam 6. szám. 698-706.

5. Christakis, N. A. és Fowler, J. H. (2010). Kapcsolatok hálójában: mire képesek a közösségi hálózatok, és hogyan alakítják sorsunkat? Bőgel György, Csermely Péter, Lovrics László kommentjeivel, ford. Rohonyi András és Rozsnyói Pál, Budapest: Typotex.

6. Fran N. (2004): Gyermekek Krízishelyzetben. Pont Kiadó, 2004.

7. Fábián G. (1997): A természetes védőháló és müködésének néhány sajátosságai Nyíregyházán. Esély (8. évf.) 3. sz. 67-75.

8. Granovetter, M.S. (1973): The Streng of Weak Ties. American Journal of Sociology, Volume 78, Issue 6.p. 1360-1380.

9. Hajduska M. (2012): Krízislélektan. ELTE Eötvös Kiadó, Budapest.

10. Hanák K. (1998): Meditáció gyermekekről-gyermekekért. In: (Hanák Katalin szerk.)- Szociológia emberközelben. Új Mandátum, Budapest 228-245.

11. Huszti É. (2008): Társas kapcsolatok. Család, rokoni, baráti kapcsolatok Nyíregyháza lakói körében. http://odin.de-efk.hu/library/100504_kapcsolatok.pdf.

12. Huszti É. (2009): Társas kapcsolatok Nyíregyházán. Szabolcs-SzatmárBeregi Szemle 4. p. 590-606.

13. Huszti É. (2009): Mint pók a hálóját. Az észak-alföldi régió ifjúsági szervezeteinek kapcsolati hálója. In: Csatári Emese (szerk.) Az Észak-alföldi ifjúsági szervezetek kapcsolati hálója egy szociológiai kutatás mentén. Nyíregyháza, Kalamáris Egyesület.

14. Huszti É. (2010): „Jönnek is a rokonok, ismerősök sorra...” Társas kapcsolatok Nyíregyházán. In: A Nemzetközi III. Nyíregyházi Doktorandusz (PhD/DLA) Konferencia Kiadványa. Nyíregyháza, Szent Atanáz Görög Katolikus Hittudományi Főiskola. p. 23-28.

15. Huszti É. (2012): Társas kapcsolatok. Családi, rokoni, baráti kapcsolatok Nyíregyháza lakói körében 2008-2010. In: Fábián G., Patyán L., Huszti É. (szerk): Életminőség Nyíregyházán 2008-2010. START Nonprofit Kft. Nyíregyháza 
16. HusztiI É., Dávid B., Vajda K. (2012): Strong tie, weak tie and inbetweens: a linear measure of tie strength based on network diary datasets- ProcediaSocial and Behavioral Sciences, 79, 38-61.

17. Huszti É. (2013): Két módszer, egy minta. Az egocentrikus kapcsolati háló vizsgálata névgenerátorral és network napló módszerrel. Acta Medicina et Sociologica - Vol 4.,79-100.

18. Kucsber L. (2012): 2011. évi tavaszi Tanulmányi Diákkonferenciára kiadványa, Széchenyi István Egyetem, Győr.

19. Kürtösi ZS. (2004): A társadalmi kapcsolathálózatok nemi aspektusai, SZTE Gazdaságtudományi Kar Közleményei, JATEPress, Szeged 201-2013.

20. Nyírcsák J. (1999): Természetes támogató-rendszerek Nyíregyházán. In.: Lukácskó Zsolt, Fónai Mihály, Fábián Gergely (szerk.) Peremvidék” - szociális kutatások Szabolcs-Szatmár-Bereg megyében NyíregyházaSalgótarján: DOTE Egészségügyi Főiskolai Kar - Salgótarjáni Népjóléti Képzési Központ, 1999

21. Soós ZS. (2005): A szociális munka alapjai, Pécs.

22. Utasi Á. (1991): Családok és életstílusok. MTA Politikatudományok Intézete, Budapest.

23. Utasi Á. (2002): A bizalom hálója. Új Mandátum, Budapest.

24. Utasi Á. (2006): A szubjektív életminőség forrásai. MTA Politikai Tudományok Intézete, Budapest.

\section{Internetes hivatkozás}

1. TÁRKI honlapja: http://www.tarki.hu/hu/research/hm/ (Látogatva: 2015.05.20.)

2. HUMÁN-NET Alapítvány honlapja:

http://www.humannet.hu/index.php/hu/csaladsegites/csaladgondozas (Látogatva: 2015.05.10.)

3. Nyíregyházi álláskeresési portál honlapja:

http://nyiregyhazaallas.hu/content.php?a=NjE1MDp0aXpibC1oYXQtbXVu a2FhZG9uYWwtam9nc2VydGVzLWVsZW4tYS1mZWtldGVtdW5rYQ== (Látogatva: 2015.05.11.) 


\section{Virág Ádám}

A Debreceni Egyetem Egészségügyi Karán végzett 2013-ban Szociális Munka alapszakon, majd 2015-ben Szociális Munka és Szociális Gazdaság (SOWOSEC) mesterszakon. 2011-ben részt vett a Debreceni Egyetem Egészségügyi Kari Tudományos Diákköri Konferencián. Jelenleg a Debreceni Egyetem Bölcsészettudományi Karának Szociológus hallgatója. Tagja a Debreceni Egyetem Tehetséggondozó Programjának, emellett a Verzár Frigyes Szakkollégiumnak és az Evangélikus Roma Szakkollégiumnak is. 